\title{
Wstęp
}

\section{Pokolenie — transformacja — tożsamość}

\begin{abstract}
„[...] każde pokolenie ma swoją historię, zapisaną w kościach, unoszą się nad nim jej opary, każde pokolenie musi zmagać się ze swoją historią zapisaną w kościach, przez całe życie jest ona dla niego punktem odniesienia i to w różnoraki sposób".
\end{abstract}

Aleida Assmann ${ }^{1}$

W 2014 roku minęło dwadzieścia pięć lat od środkowoeuropejskich przełomów ustrojowych oraz dwadzieścia dwa lata od rozpadu Związku Radzieckiego. Wydarzenia te w sposób fundamentalny zmieniły polityczno-gospodarcze oraz społeczno-kulturowe oblicza tej części Europy. Przez minione ćwierć wieku zdążyło też dorosnąć pokolenie, które po raz pierwszy osobiście nie zaznało wojennej traumy oraz wpływu totalitaryzmu w jego komunistycznym wcieleniu; pokolenie, dla którego wolność była normalnym, jedynym i obiektywnym stanem egzystencji. Nie ulega wątpliwości, że pokolenie to zostało ukształtowane przez konsekwencje wspomnianych przełomowych wydarzeń, to znaczy: demokrację, dobrobyt, możliwość swobodnego poruszania się po świecie, szeroką ścieżkę rozwoju edukacyjnego i zawodowego (bez konieczności ograniczania się tylko do rynku krajowego) etc. Zatem wspólne doświadczenia transformacyjne, podobne wzorce socjalizacji (konstruowane przez nową technikę cyfrową, nowe formy konsumpcji, nowe światy medialne) oraz współdzielone struktury wartości złożyły się, jak pisze Aleida Assmann, na określone piętno, które odcisnęło się na życiu tego pokolenia, stając się jego tożsamościową podwaliną zarówno na poziomie indywidualnym,

${ }^{1}$ A. Assmann, Historia ucieleśniona - o dynamice pokoleń, tłum. I. Drozdowska-Broering, [w:] Pokolenia albo porządkowanie historii, wybór, wstęp i oprac. H. Orłowski, Poznań 2015, s. 725. 
jak i zbiorowym ${ }^{2}$. Jednak żadne pokolenie nie jest bezludną wyspą na oceanie dziejów. Każde uczestniczy w określonym ciągu generacyjnych wydarzeń, mając z jednej strony wpływ na to, co będzie w nieodległej przyszłości, a z drugiej - będąc w mniejszym lub większym stopniu osadzone w tym, co było. Badacze zgodnie podkreślają, iż pamięć odgrywa niebagatelną rolę w formowaniu się pokoleń, nadawaniu im charakteru, określaniu ram, w których odnajdują się jego członkowie. Pytania o to, na ile pokolenia posiadają własną pamięć, co należy do jej elementów i jak kształtuje ona świadomość poszczególnych członków konkretnego pokolenia, należy zaliczyć do tych bardziej interesujących z zakresu refleksji nad przemianami społeczeństwa ${ }^{3}$.

Nie bez kozery Pierre Nora postrzega pokolenie jako „mieszaninę pamięci i historii", w której - w zależności od danego momentu dziejowego - zmieniają tylko proporcje obu wymienionych składników ${ }^{4}$. Pokolenie jest dla niego miejscem pamięci uobecniającym czy też uosabiającym przeszłość z myślą o zdefiniowaniu swej tożsamości, ponieważ „poszukiwanie pamięci to próba znalezienia własnej historii”" . Problem ów nabiera szczególnego znaczenia w świetle form tożsamości postmodernistycznych, skazanych na (auto)definiowanie się poprzez odniesienie do przeszłości na drodze jej ciągłości bądź zerwania z nią ${ }^{6}$. Dlatego też w relacji pamięć-pokolenie kardynalne znaczenie ma transfer wewnątrz-i międzypokoleniowy. Zachwianie jego równowagi, spowodowane przeważnie traumatogennymi czynnikami historycznymi, politycznymi czy społecznymi oraz tej samej natury urazami potraumatycznymi, prowadzi do rozłamu pokoleniowego (generation gap). Zjawisko to występuje także wówczas, gdy nowe formy kulturowe wypierają i zastępują stare. Taka właśnie sytuacja zaistniała na europejskiej arenie społeczno-kulturowej po upadku muru berlińskiego oraz rozpadzie ZSRR.

Należy jednak mieć na uwadze fakt, że pokolenie Europejczyków, które dorastało po przemianach ustrojowych końca lat osiemdziesiątych i początku dziewięćdziesiątych XX wieku, jest wyjątkowe, albowiem wychowywało się w dobie pośrednich przekazów o epoce totalitaryzmów, bez stanu „wyższej konieczności” troski o zachowanie tożsamości narodowej i bez znaczącego historycznie (w skali europejskiej czy globalnej) przełomowego wydarzenia, jakiemu można by nadać miano przeżycia pokoleniowego, stanowiącego spoiwo dla ich pokoleniowości, w której świetle odbierane byłyby zarówno te wcześniejsze, jak i teraźniejsze oraz późniejsze

${ }^{2}$ Zob. ibidem, s. 693, 695.

${ }^{3}$ K. Malicki, Pamięć przeszłości pokolenia transformacji, Warszawa 2012, s. 34-35.

${ }^{4}$ Zob. P. Nora, La génération, [w:] Les lieux de mémoire, red. P. Nora, Paris 1997, t. II, s. $2975-$ 3015.

${ }^{5}$ P. Nora, Między pamięcia a historia: les lieux de memoire, przeł. M. Borowski, M. Sugiera, „Didaskalia" 2011, nr 105, s. 22.

${ }^{6}$ Zob. A. Kraft, M. Weisshaupt, Doświadczenie - narracja - tożsamość a granice rozumienia: rozważania o pojęciu pokoleń, tłum. J. Kałążny, [w:] Pokolenia albo porządkowanie historii, s. 265 n. 
zdarzenia $^{7}$. Ów brak bagażu dziedzictwa realnego socjalizmu (właściwego pokoleniom ich dziadków czy rodziców) okazuje się istotnym czynnikiem warunkującym normy, wartości i wzorce zachowań, mające wpływ na kształtowanie się aspiracji, interesów, postaw i sposobów działania uczestników tego pokolenia. Dla pełnego oglądu sytuacji wśród czynników określających tożsamość tego pokolenia trzeba wymienić również globalizację oraz konsumpcjonizm, które - manifestując swoje oddziaływanie na czas pracy, czas wolny oraz życie rodzinne wzmiankowanej generacji - stanowią pokoleniową reakcję na specyfikę sytuacji historycznej danego miejsca i czasu, w jakim przyszło jej żyć ${ }^{8}$. W ten sposób pokolenie transformacyjne w krajach byłego bloku socjalistycznego po upadku żelaznej kurtyny zaczęło w przyśpieszonym tempie nadrabiać zaległości cywilizacyjne i coraz mocniej upodabniać się do swoich rówieśników z ponowoczesnych społeczeństw Zachodu.

Zwróćmy jednak uwagę, iż tego typu tendencje były właściwe społeczeństwom Europy Środkowej i Wschodniej. Natomiast zupełnie inaczej wyglądała sytuacja w krajach byłej Jugosławii, które w tym czasie pogrążały się w chaosie rozpadu kraju i podsycanej historią wojnie, jaka bezsprzecznie pozostawiła swe tragiczne i głęboko traumatyczne piętno zarówno na pokoleniach bezpośrednio nią dotkniętych, jak i tych, które znają ją dziś i znać w przyszłości będą jedynie z przekazów poprzednich pokoleń.

Nieodparcie nasuwa się też pytanie, jak i w jakim stopniu pokoleniotwórcze okażą się dla dzisiejszych mieszkańców Europy Środkowej i Wschodniej oraz Południowo-Wschodniej zaistniałe $\mathrm{w}$ naszym dziesięcioleciu wydarzenia, takie jak migracja uchodźców z Bliskiego Wschodu, wzmożona fala terroryzmu islamskiego czy też działania wojenne we wschodnich regionach Ukrainy, poprzedzone wydarzeniami „rewolucji godności”, rozgrywającej się w Kijowie na przełomie 2013 i 2014 roku.

Spośród wszystkich dziedzin sztuki teatr zdaje się optymalną platformą do zaistnienia i współinspirującego zrealizowania się symbiozy pokolenia, tożsamości i pamięci. Wszak teatr, będąc instytucją na wskroś społeczną, z istoty swej niejako zobowiązany jest do kodowania historii, a co za tym idzie, deponowania pamięci o niej oraz przekazywania jej kolejnym pokoleniom w wyniku memorialnej komunikacji. Jak pisał Frieddie Rokem, „[T]eatr aktywnie uczestniczy w procesie przedstawiania i problematyzowania przeszłości, wzmacniając czy podważając dominujące rozumienie dziedzictwa historycznego, które stanowi podstawę konstruowania toż-

7 Por. J. Garewicz, Pokolenie jako teoria socjofilozoficzna, „Studia Socjologiczne” 1983, t. 1, s. 77.

${ }^{8}$ Zob. W. Wrzesień, Europejscy poszukiwacze. Impresje na temat współczesnego pokolenia polskiej młodzieży, Warszawa 2009. 
samości kolektywnej”9. Zatem teatr i pamięć stanowią dla siebie niejako symetryczne zwierciadła czy też wzajemnie podsycające i uzupełniające się źródła niewyczerpanej energii. Dlatego też teatr jest nie tylko medium pamięci, lecz także jej kreatorem ${ }^{10}$.

Po roku 1989 związek pamięci z przeszłością, a dokładniej proces przywracania pamięci o przeszłości, przetransponowany na różnorakie warianty pokoleniowej narracji ${ }^{11}$, stał się żywą materią teatralnego procesu Europy Środkowej i Wschodniej oraz krajów byłej Jugosławii. Proces ów zaznaczył się zarówno w materii przedstawień podejmujących kwestie historii i pamięci, jak i w określonych strategiach scenicznych i konwencjach teatralnych, począwszy od rekonstrukcji historycznych, poprzez przedstawienia o tematyce historycznej, po działania performatywne, wykorzystujące techniki kolażu, przeróbki, a skończywszy na przepisywaniu czy też remiksowaniu historii ${ }^{12}$.

Co ciekawe, czas, historia i pamięć nie od razu stały się „palącym wyzwaniem” dla teatru doby transformacji (co skądinąd zrozumiałe, wziąwszy pod uwagę, jakim ideologiczno-propagandowym balastem była obciążona historia w społeczeństwach znajdujących się w strefie radzieckiej dominacji) ${ }^{13}$. Najpierw, w pierwszej dekadzie poprzełomowej, następuje programowe odwrócenie się od świata zewnętrznego, a jeśli już ten był przywoływany, to pod postacią ironii, groteski. Wówczas teatr, a wraz z nim i dramat, skupia się na uporządkowaniu chaosu świata wewnętrznego, z którym przyszło się zmierzyć jednostce po upadku starego porządku systemowego. Teatr próbuje okiełznać lęki nowej, nieznanej nadchodzącej epoki, w której człowiek został postawiony przed koniecznością samodzielnego kreowania swej rzeczywistości oraz wzięcia za tę autokreację całkowitej odpowiedzialności. Zatem pierwsza dekada teatru po przełomach lat 1989 i 1991 to skoncentrowanie się na prywatności i intymności, choć wpisane w szersze działanie, jakiego wówczas podjęli się twórcy teatralni, czyli próby zdefiniowania na nowo tożsamości narodowej, społecznej i kulturowej krajów usiłujących podźwignąć się z wieloletniego uzależnienia od sowiec-

${ }^{9}$ F. Rokem, Wystawianie historii. Teatralne obrazy przeszłości we współczesnym teatrze, tłum. M. Borowski, M. Sugiera, Kraków 2010, s. 21.

10 Por. „[...] sposób, w jaki konstruowana jest historia, w jaki definiuje się jej funkcje wychowawcze i edukacyjne, a zatem sposób, w jaki prezentuje się społeczeństwu przeszłość, zawsze znajduje odzwierciedlenie w konwencjach teatralnych, także wówczas, gdy teatr tym oficjalnym narracjom się przeciwstawia. Dokonujące się obecnie rozbijanie narracji historycznych w postaci, w jakiej przekazała nam je tradycja, odchodzenie od uniwersalizacji i standaryzacji wizji przeszłości na rzecz nowych dyskursów historycznych sprawia, że teatr także poszukuje nowych sposobów wystawiania historii i okazuje się zaskakująco kreatywny w zakresie odsłaniania zatartych śladów przeszłości”. M. Leyko, Historia w teatralnym remiksie, „Dialog” 2014, nr 3, s. 126.

${ }^{11}$ Por. R. Pawłowski, 25 lat teatru w wolnej Polsce. Czy jest wspólnota?, „Gazeta Wyborcza”, 17.04.2014, http://wyborcza.pl/1,75475,15814341,25_lat_teatru_w_wolnej_Polsce_Czy_jest_wspolnota_.html [dostęp: 7.11.2015].

12 Por. A. Sobiecka, Teatralne remiksowanie historii jako wariant historii lokalnych, [w:] Teatr historii lokalnych w Europie Środkowej, red. E. Wąchocka, D. Fox, A. Głowacka, Katowice 2015, s. 305-322.

13 Por. E. Brix, Rola historii w politycznej przemianie Europy Środkowej, [w:] idem, Z powrotem w Europie Środkowej. Eseje i szkice, tłum. A. Śliwa, Kraków 2012, s. 109-122. 
kiej hegemonii politycznej, gospodarczej, kulturowej i mentalnej. Wraz z nowymi wyzwaniami transformacyjnymi $\mathrm{w}$ teatrze pojawia się nowe pokolenie reżyserów i dramaturgów, którzy usiłują określić na nowo status, rolę i znaczenie teatru w społeczeństwie zmierzającym do demokracji. Jak celnie zauważył Roman Pawłowski (co prawda w odniesieniu do teatru polskiego, ale podobne prawidłowości dają się zaobserwować w teatrze pozostałych krajów postkomunistycznych, o czym najlepiej świadczą teksty zamieszczone w niniejszym tomie), teatr zaczął być przez nich traktowany jako miejsce i środek wyrazu autoekspresji.

Można powiedzieć - jak pisze Pawłowski — że ta generacja sprywatyzowała emocje, zmieniając perspektywę ze zbiorowej na intymną. Ich przedstawienia przekraczały tabu religijne i obyczajowe, wydobywały na światło dzienne ukrywane na co dzień tematy: kwestię tożsamości seksualnej, depresji, toksycznych związków rodzinnych ${ }^{14}$.

Dopiero nowe stulecie wprowadziło do teatru postkomunistycznej Europy problematykę polityczno-historyczną, poprzez którą teatr zachęcał i prowokował do podjęcia wysiłku przywracania/odzyskiwania kolektywnej pamięci społeczeństw wychodzących z realnego socjalizmu. Nie czynił tego jednak z perspektywy wielkiej historii, lecz w nowej optyce: mikronarracji jednostki, której przychodziło się mierzyć $\mathrm{z}$ „walcem” dziejów. Teatr pierwszego dziesięciolecia XXI wieku nie stroni też od dekonstruowania zbiorowej pamięci i z myślą o publicznej debacie śmiało wyciąga na światło dzienne "trupy przeszłości” (zarówno tej dalszej, jak i bliższej), które nieopłakane, domagały się zadośćuczynienia i ofiary. Jednocześnie twórcy teatralni podejmują również najbardziej aktualne „bolączki”, wynikające ze zderzenia posttotalitarnych społeczeństw z mechanizmami i procesami globalizacji, konsumpcjonizmu, kryzysu moralnego, powszechnej dewaluacji autorytetów, przemocy i nierówności, które przyniosła $\mathrm{z}$ sobą postmoderna oraz ponowoczesność. W efekcie coraz większą rolę zaczęły odgrywać teatry lokalne, koncentrujące się na tożsamości lokalnej czy też środowiskowej.

Jednak czas transformacji prodemokratycznej wymusił na teatrze Europy Środkowej i Wschodniej oraz Południowo-Wschodniej zmiany nie tylko w płaszczyźnie sensu stricto artystycznej; musiał on zmierzyć się również z nowymi, wolnorynkowymi realiami ekonomiczno-organizacyjnymi neoliberalnej rzeczywistości, które okazały się wyjątkowo dotkliwe, zwłaszcza w świetle konieczności ustanowienia nowych relacji z mecenatem (przejście od mecenatu państwowego, jaki już niemalże nie istniał, do mecenatu prywatnego, którego status znajdował się dopiero w fazie formułowania się). Wreszcie niebagatelnym wyzwaniem było określenie nowych zadań i obowiązków wobec publiczności, która w zatrważającym tempie zaczęła opuszczać sale teatralne na rzecz masowej kultury popularnej, wartkim i szerokim strumieniem wpływającej do kultury poszczególnych państw byłego bloku socjalistycznego po upadku żelaznej kurtyny. Dlatego też, aby zatrzymać odpływ widzów z teatru, na

${ }^{14}$ R. Pawłowski, 25 lat teatru w wolnej Polsce. Czy jest wspólnota? 
scenie pojawił się nowy repertuar, który zaczął przemawiać do publiczności w języku jej właściwym i o rzeczywistości jej bliskiej. Jednoczesne zachowanie wartości artystycznych, charakterystycznych dla teatru jako sztuki wysokiej, wymagało od twórców nie lada ekwilibrystyki. W rezultacie w estetyce teatralnej zjawiły się nowe środki wyrazu, wywodzące się z kultury masowej: filmu, wideo, telewizji, mediów cyfrowych oraz performance'u czy tańca, które otworzyły teatr na nowe mechanizmy narracyjne i nowe sposoby konstruowania obrazów scenicznych, a także na nowy, mocno autorski język teatralny, prowokujący odbiorcę do intelektualnego wysiłku prowadzącego do poddania ocenie przeniesionej na wyżyny teatralnej realności kultury popularnej i jej produktów wytwarzanych na masową skalę. Dzięki temu dialog $\mathrm{z}$ transformacyjną publicznością został zachowany. Podtrzymaniu komunikacji z widzem służyło również wyprowadzenie teatru poza teatr, do przestrzeni nieteatralnych, z silnym nacechowaniem semantycznym (np. centra handlowe, opuszczone fabryki i zakłady przemysłowe, lotniska etc.), dzięki czemu przedstawienia zyskiwały nowe ekspresyjne walory, skutecznie pobudzające wyobraźnię odbiorcy ${ }^{15}$.

Z całą pewnością można więc stwierdzić, że teatr w kulturach postkomunistycznych Europy Środkowej, Wschodniej oraz byłej Jugosławii stał się wyjątkowo jaskrawym i czytelnym świadectwem transformacji systemowej z przełomu lat osiemdziesiątych i dziewięćdziesiątych; okazał się swoistym lustrem dla jej najistotniejszego przesłania, utwierdzającego społeczeństwa postkomunistyczne w przekonaniu, że dokonana zmiana, choć bolesna, jest nieodwracalna.

Prezentowany tom stanowi pokłosie międzynarodowego projektu naukowo-kulturalnego Ukraina - Polska - Europa, zrealizowanego w dniach 14-15 listopada 2014 roku przez Zakład Ukrainistyki oraz Pracownię Interdyscyplinarnych Studiów nad Posttotalitaryzmami przy Instytucie Filologii Słowiańskiej, jak też Zakład Teorii Kultury i Sztuk Widowiskowych Instytutu Filologii Polskiej Uniwersytetu Wrocławskiego wespół z Europejskim Ośrodkiem Praktyk Teatralnych „Gardzienice”. Inicjatywa ta została sprowokowana wydarzeniami, jakie rozegrały się zimą 2013/2014 roku na kijowskim Majdanie Niezależności. To właśnie chęć upamiętnienia tamtych dramatycznych dni przyświecała inicjatorom tego projektu - Ireneuszowi Guszpitowi z Uniwersytetu Wrocławskiego i Włodzimierzowi Staniewskiemu, dyrektorowi EOPT w Gardzienicach, oraz piszącej te słowa. Ireneusz Guszpit od początku wspomnianych wydarzeń był swoistym „rezonerem” moich ówczesnych wrażeń z pobytów na Ukrainie w tamtym majdanowym i pomajdanowym czasie. Natomiast Włodzimierz Staniewski, żywo poruszony rewolucją ukraińską, zetknął się podczas jednej z rozmów z Ireneuszem Guszpitem z moimi wrażeniami i przemyśleniami

15 Por. J. Wachowski, Przemiany w sztuce widowiskowej po roku 1989, „Horyzonty Polonistyki” 2007, nr 3, s. 42. 
na temat ówczesnych aktualiów ukraińskich i zaproponował organizację wspólnego przedsięwzięcia na rzecz Ukrainy. Za to wsparcie moich działań popularyzujących kulturę ukraińską obu Panom gorąco dziękuję.

Osobne podziękowania należą się Dziekanowi Wydziału Filologicznego Uniwersytetu Wrocławskiego, Panu Profesorowi Marcinowi Cieńskiemu, oraz Dyrekcji Instytutu Filologii Słowiańskiej, bez których przychylnego wsparcia finansowego wspomniana inicjatywa nie mogłaby zostać zrealizowana.

Projekt Ukraina - Polska - Europa obejmował zarówno wydarzenia teatralne, jak i artystyczno-literackie oraz naukowe. W części teatralnej zaprezentowane zostały przedstawienia Ośrodka Praktyk Teatralnych „Gardzienice” (Ifigenia w T... i Oratorium Pytyjskie) oraz premierowy spektakl „SIEDEM” grupy teatralnej „STUDiO A.K.T." z Kijowa (reż. Oleg Dracz), będący ukoronowaniem rezydencji trupy w Gardzienicach.

Z kolei część artystyczno-literacka obejmowała wystawę fotograficzną Tętno Majdanu autorstwa Ołeksija Karpowycza (oraz spotkanie z nim samym), a także cykl spotkań z pisarzami, które odbywały się pod wspólnym szyldem „Za co kochamy Wschód?", z udziałem Andrzeja Stasiuka, Serhija Żadana, Tarasa Prochaśki oraz Władimira Rafijenki i Jurija Wołodarskiego — twórców, każdy na swój sposób, zaintrygowanych wschodem Ukrainy, będącym wówczas w centrum uwagi międzynarodowej ze względu na eskalację rozgrywającego się tam konfliktu rosyjsko-ukraińskiego. Zapis przeprowadzonych wówczas wywiadów został w prezentowanej publikacji umieszczony w rozdziale Co z tą Ukraina? Wywiady poprzedzają dwa przekrojowe teksty: Majdan 3.0 w perspektywie wczoraj i dziś. Rys pokoleniowy oraz Międzyrzecze kultur. Rzecz o współczesnej rosyjskojęzycznej literaturze ukraińskiej; oba teksty stanowią wprowadzenie do problematyki podjętej w rozmowach z pisarzami.

Trzon merytoryczny prezentowanej publikacji stanowią artykuły, będące pokłosiem dyskusji panelowej nt. Teatr i dramat $w$ kulturach posttotalitarnych Europy Środkowej, Wschodniej i Południowo-Wschodniej, w której wzięli udział naukowcy z Polski, Słowacji, Słowenii i Ukrainy. Myśl przewodnią panelu stanowi transnarodowa analiza świadomości posttotalitarnej z perspektywy transformacyjnego przełomu pokoleniowego oraz jego znaczenia dla społeczno-kulturowych procesów końca XX i początku XXI wieku. Problematyka ta została omówiona w odniesieniu do dramatu i teatru białoruskiego, czeskiego, niemieckiego, polskiego, rosyjskiego, słowackiego, ukraińskiego oraz krajów byłej Jugosławii.

Intencja tak pomyślanej debaty była sprowokowana ideą porównania zarówno ogólnych, jak i szczegółowych procesów, które są właściwe dla dramatu i teatru w okresie transformacyjnej zmiany od totalitaryzmu do liberalnego stanu świadomości kulturowej. Natomiast zwrócenie uwagi na zmianę pokoleniową, traktowaną jako jeden z kluczowych markerów kulturowych okresu przejściowego, miało po- 
zwolić sprawnie zdiagnozować i opisać „Zranione i bolące miejsca” świadomości posttotalitarnej, a także umożliwić dokonanie analizy, w jaki sposób i w jakim stopniu owa świadomość odcisnęła swoje signum na dramacie i teatrze europejskim po przełomach demokratycznych z lat 1989 i 1991.

Wśród zagadnień szczegółowych poddanych pod dyskusję znalazły się następujące kwestie:

- przełom pokoleniowy jako jeden z rodzajów dyskursów warunkujących przestrzeń kluczowych konfliktów we współczesnym dramacie i teatrze krajów byłego bloku socjalistycznego;

- świadomość pokoleniowa w procesie przepracowania traumatycznego doświadczenia totalitarnej przeszłości;

- pamięć kulturowa a konflikty społeczno-kulturowe wykreowane przełomem pokoleń z lat 1989 i 1991;

- mechanizmy kształtowania się świadomości pokoleniowej w różnych okresach historycznych i ich porównawcze zestawienie z okresem transformacji po roku 1989 i 1991.

Tak wytyczone obszary tematyczne nie stanowiły zamkniętej ramy, o czym mogą świadczyć prezentowane w niniejszym tomie teksty. Mam nadzieję, że staną się one inspirującą zachętą do dalszych porównawczych dyskusji nad teatrem i dramatem w kulturach posttotalitarnych Europy Środkowej, Wschodniej i Południowo-Wschodniej.

Wrocław, 15 listopada 2015 roku

Agnieszka Matusiak 